\title{
Yaşam Becerilerinin Kazandırılmasında Yaratıcı Drama Yönteminin Kullanılması*
}

\author{
Selçuk Rafet SEFER ${ }^{1}$ \\ O. Nejat AKFIRAT ${ }^{2}$ \\ Milli Eğitim Bakanlığ
}

\begin{abstract}
$\ddot{O}_{z e t}$
Yaratıcı drama yöntemi kullanılarak yaşam becerileri konusunda farkındalık yaratmak amacıyla hazırlanan bu çalışma, İstanbul ili Üsküdar ilçesi Milli Ĕgitim Müdürlüğ̈̈'ne bă̆lı Mihriban Suat Bedük İlköğretim Okulu 8. sinıfinda okuyan 15 öğrencinin katılımıyla yapılmuştır. Araştırma verileri uzman görüşleriyle hazırlanan görüşme formu kullanılarak toplanmıştır. Veriler içerik analizi yapılarak değerlendirilmiştir. Araştırma bulgularına göre, yaşam becerilerinin kazandırılmasında yöntem olarak yaratıcı dramanın kullanılmasının katılımcıların ögrrenmeleri üzerinde olumlu etki yaptığı görülmüştür. Yaratıcı dramanın, klasik yöntemlere göre, katılımcıları daha fazla aktif olmasını sağlaması, oyunlarla ve canlandirmalarla desteklenmesinin, katılımcıların kendilerini rahat ifade edebilecekleri bir ortam yaratmasının motivasyonlarını artırdı̆̆ ve ögrenmelerini kolaylaştırdı̆̆ı belirlenmiştir. Ayrıca yöntemin, katılımcıların kişisel gelişimleri açısından önemli olan yaşam becerilerini ve buna bağlı olarak kişisel özelliklerini tanımalarına olanak tanıdı̆̆g, özellikle bu yönde katılımcılarda farkındalık yarattı̆̆ söylenebilir.
\end{abstract}

Anahtar Sözcükler: Yaratıcı drama, yaşam becerileri, iletişim, kendini tanıma, özgüven, hayır diyebilme, problem çözme.

\begin{abstract}
This study, which was prepared for the purpose of creating awareness about living skills with using creative drama methods, was performed with participation of 15 students educated in 8. grade at Mihriban-Suat Bedük elementary school connected to Istanbul province Üsküdar district Directorate of National Education. Research data was gathered using interview forms which was prepared with specialist opinions. The data was evaluated with content analysis. According to research findings, using creative drama as a method on gaining living skills, it was seen positive effect on participants' learning. It was stated that creative drama, in comparison to classical methods, increases participants' motivations and makes their learning easy, with providing more active participants, supporting with games and animations, creating an environment that participants can express themselves with ease. Besides, it can be said that this method enables recognizing of participants'living skills and in parallel with their personal features which is important in terms of their personal developments, especially it creates awareness on participants in this direction.
\end{abstract}

Key words: Creative drama, living skills, communication, self-knowledge, self-confidence, can say no, problem solving

\section{Giriş}

Yaşam, bireyin özgürlüğünü üretme ve sürdürme çabalarıyla özgünlüğünü koruyabilme mücadelesinin yanında birlikte yaşamanın gerektirdiği becerilerinin kazanılması arayışlarından oluşan bir süreç olarak ifade edilebilir. Bu bakış açısıyla değerlendirildiğinde, yaşam; bireyi her aşamasında temel bir ikilem ile karşı karşıya getirir. Bu ikilem; bireyin eş zamanlı olarak, aynı yaşam sürecinde hem kendisi olmayı

Bu makale, MEB Özel Doğaç Yaratıcı Drama Liderliği/Eğitmenliği Kursu bitirme Projesi’nden geliştirilerek yazılmıştır.

1 Bil. Uzm. Milli Eğitim Bakanlı̆̆ı, E-posta: srsefer@gmail.com

2 Dr. Milli Eğitim Bakanlığı, E-posta: nejatakfirat@gmail.com 
hem de birlikte yaşamayı gerçekleştirebilmesi gerekliliği şeklinde ifade edilebilir.

Yaşam becerileri, bireyin değişim sürecinde varlığını etkin bir şekilde sürdürebilmesi için sahip olması gereken yeterliliklerdir (Erbil vd., 2000).

Genel olarak, yaşam becerileri gelişimin psikolojik, fiziksel, cinsel, mesleki, bilişsel, ahlaki, duygusal ve benlik yönlerine odaklanmışlardır (Picklesimer, Miller, 1998). Yaşam becerileri eğitim programları, teşhis ve etiketlemeden uzak durarak madde kullanımı ve bağımlılık ile bağlantılı damgalanma ve utanç duygularını azaltır. Ergenler, yaşamla nasıl başa çıkacaklarını öğrenecekleri yeni deneyimlerle daha fazla ilgileneceklerdir. Bu açıdan bakıldığında davranış değişikleri "iyileşme ve düzelme"den çok bir “keşif yolculuğu”na dönüşür (Hawkins, Cummins, Marlatt, 2004).

Yaşam becerileri ile ilgili bir başka tanım ise teknik becerilerden çok, insanların günlük yaşamlarını ve çalışma hayatındaki sorumluluklarını gerçekleştirmek için kullandıkları beceriler olarak belirlenmiştir. $\mathrm{Bu}$ beceriler daha çok iş yaşamına yönelik becerilerdir.

Ayrıca yaşam becerileri olarak belirlenen diğer önemli beceriler: metin okuma, dokümanların kullanımı, yazma, matematik, sözlü iletişim, düşünme becerileri, iş planlama ve düzenleme, hafizanın etkin kullanımı, bilgiye ulaşma, iş birliği, bilgisayar okuryazarlığı, sürekli öğrenmedir (Yaşam Becerileri, 2009).

Iowa Çocuk Gelişimi Bürosu’nda hazırlanan “Targeting Life Skills” (TLS) Modeli'nde, gencin gelişiminin; onu yaşadığı toplumun gelenek ve kanunlarına uygun, üretken ve tatmin edici bir yaşama hazırlamak için gerekli zihinsel, fiziksel, toplumsal ve duygusal gelişim süreci olduğu belirtilmektedir. Gençlere yönelik program ve öğretim programı geliştiren kişilerin, gençlerin ihtiyaç duydukları bilgilere ulaşacağı ve becerilerini geliştirebilecekleri eğitim firsatları sunmaları gerektiği belirtilmektedir. Bir programın başarılı olması için; alan konularını verirken, yaşam becerilerinin geliştirilmesi, hedeflere ulaşılmasını sağlayacak şekilde planlanması ve gençlerin yaşamlarında ihtiyaç duyacakları becerileri kazandırmasıyla mümkün olduğu savunulmaktadır. Modelde yaşam becerileri, bireylerin yaşamda üretken ve mutlu olmaları için geliştirilecek yeterlilikler olarak tanımlanmaktadır. Yaşam becerilerinin hedefi: Gençlere yaşam becerilerini kazanacakları gelişimsel olarak uygun firsatlar sağlamak, Bu becerilerin öğrenilene kadar tekrar edilmesi ve gençlerin yaşamları süresince ihtiyaç duyduklarında kullanabilmeleri olarak belirlenmiştir. Süreç içinde genç, bu bilgileri içselleştirir ve uygun biçimde kullanma yeterliliğine ulaşır (Life Skills, 2009).

Yaşam becerileri, etkili bir hayat için gerekli olan ve akademik becerilerden farklı beceri ve bilgilerdir. Yaşam becerileri, teşhis ve etiketlemeden uzak durarak damgalanma ve utanç durumunu azaltır. Öğrenciler, yaşamla nasıl başa çıkacaklarını öğrenerek yeni deneyimlerle daha fazla ilgileneceklerdir. Söz konusu yaş grubundaki öğrencilerin özellikle yaşama bakış ve yaşamdan beklentileri göz önüne alındığında yaşam becerileri bilgilerine sahip olmalarının karşılaştıkları sorunlar ve engellerle başa çıkmada olumlu etkileri olacağı düşünülmektedir. Ayrıca bir eğitim basamağından diğer eğitim basamağına geçişte öğrencilerin özellikle farkındalıklarını artırma ve uyum sürelerini azaltma konusunda etkili olacağ varsayılmaktadır. Tüm bunlar göz önüne alındığında yaşam becerileri ile ilgili temaların yaratıcı drama ile verilmesinin yaratıcı dramanın yapısı gereği daha etkili sonuçlar vereceği düşünülmektedir. 
Öğrencilerin ilgilerini canlı tutmanın ve onları motive etmenin en kolay yolu öğrenme esnasında öğrencileri aktif kılmak ve öğrencilerin geçmiş yaşantılarından yararlanmaktır. Yaratıcı drama da, eğitimde buna hizmet eden yöntemlerden biridir. $\mathrm{Bu}$ anlamda yaratıcı drama yönteminin, eğitim ortamında değişik konuları öğretmek gibi bir amacı vardır. Çocukların ve ergenlerin ilgilerini genişletmek, gerçekliğe imgeleme aracılığı ile bakabilmeleri ve ulaşabilmelerini, onların oynamaktan çok anlamalarını sağlamak bu amacın içerisinde yer alır (Adıgüzel, 1993).

Nickel'e (1986) göre, eğitimde yaratıcı dramanın amacı, bir kavramın, bir ders konusunun, bir ders metninin daha iyi anlaşılmasını sağlaması; bireyce ve grupça özümsenip içsel yaşantıya dönüşmesi, gözden geçirilerek, üzerinde düşünülerek dışa vurulmasıdır (Akt: Adıgüzel, 1993).

Temel eğitimin öğrencilere kazandırmayı hedeflediği ve toplumdaki tüm bireylerin sahip olması beklenen yaşam becerilerinin, yaratıcı drama yöntemi ile işlenmesinin öğrenciler tarafından daha etkili ve kalıcı bir şekilde öğrenilmesini sağlayacağı düşünülmektedir.

Bu çalışmada yaşam becerilerinden beş tanesi üzerinde durulmuştur. Bunlar; iletişim, kendini tanıma, özgüven, "hayır" diyebilme, problem çözme becerileridir.

İletişim: Geniş anlamda "kişi ve çevresi arasında iki yönlü ilişkiyi ilgilendiren aşamalar" olarak tanımlanabilir. Dinamik, akıcı, devamlı ve değişken bir süreçtir. İletişimi "herhangi bir işaret yardımı ile duygu, düşünce ve anlamların nakli ya da değiş tokuşu” olarak da tanımlayabiliriz. (Oskay, 2001).

Özer (2001), iletişimin insanlar arasında olması gereken ama yeterince olmayan bir beceriler bütünü olduğunu ifade etmiştir. İletişim becerisi kişiden karşı karşıya kaldığı olayla ilgili olası bakış açılarını ve tanımlamaları araştırmayı, soruşturmayı ve bütünleştirmeyi içerir. Bu beceriyi kazanmış birisi kendisine yöneltilen bir uyarı, eleştiri veya şikâyet karşısında tek açı yerine çok açıdan anlam verme yeteneğine sahip olabilecektir. İnsan ilişkileri içinde sürekli yeniden tanımlanan bir varlıktır. Diğer insanlarla hiç ilişkisi olmayan bir insan düşünülemez (Cüceloğlu. 1991).

Kendini Tanıma: Bireyin bedeni, düşünce ve duygularıyla ilişki kurması ve kendisinde olup biten duygusal ve düşünsel süreçlerle ilgili bir anlayışa kavuşmasıdır. Yani, benliğimizin sınırlarının farkına varmak, güçlü/zayıf ve gelişmeye açık yönleri bilmek, olumsuz yönlerimizle yüzleşebilmek, duyguları tanımak ve davranışlarımızın anlamını büyük ölçüde fark edebilmek ve bizi etkileyen fiziksel, felsefi ve çevresel etkileri fark etmektir. Beden, düşünce ve duygularımızın birbirleriyle ilişkisini kurabilmek, kendimizdeki duygusal, düşünsel ve davranışsal süreçlerle ilgili bir anlayış geliştirmektir (Kendini Tanıma, 2009). Bir insanın kendini tanıması için bilgileri, becerileri, istekleri ve inançları ile ilgili tam ve doğru bilgi sahibi olması gerekir. Bunları doğru tanımlayan, açık ve dürüst bir şekilde ifade eden, anlatırken doğru sözcükleri seçerek kendi değerini azaltmayan ya da abartmayan bir kişi işinde ve sosyal ilişsilerinde daha başarılı, mutlu, huzurlu ve güvenli olacaktır (Kendini Tanıtma, 2009).

Özgüven: Bireyin kendisine yönelik iyi, olumlu duygular geliştirmesi sonucu kendini iyi hissetmesidir. $\mathrm{Bu}$ iyi hissetme sonucunda kendisiyle ve çevresindeki kişilerle barışık olması demektir (Akagündüz, 2006). 
Özgüven psikolojik olarak var olabilmenin esasını oluşturur. Benlik bilinci insanı hayvanlardan ayıran özelliklerden biridir: Diğer bir deyişle, kişi kim olduğunu tanımlama ve söz konusu kimliği beğenip beğenmediğine karar verme yeteneğine sahiptir (Mckay ve Fanning, 1998).

Çocuklar ergenlikle beraber özgüvenlerini değerlendirmeye ve şekillendirmeye baslar. İlk yıllarda ailenin çocuğa verdiği mesajlar doğrultusunda gelişen özgüven, çocuğun okula başlamasıyla ailenin yanı sıra öğretmen ve arkadaşları gibi diğer kaynaklardan beslenir (Özbey, 2004).

"Hayır" Diyebilme: Gruplar, üyelerine belirli kuralları kabul ettirme ve belirli davranış kalıplarını aşılama eğilimindedir. Grubun üyesi olmak, grup kurallarına uymak ve kendinden beklenen davranışları sergilemek durumundadır. Aksi halde birey, gruptan dışlanacak ya da başka bir ceza ile karşı karşıya gelecektir. Grup içinde bulunan bireylerin davranış ve düşünceleri, onlar üzerinde grubun psikolojik bir baskısı olması nedeniyle giderek birbirine benzer türden davranış ve düşüncelere dönüşmektedir (Masalc1, 2001).

Ergenler çevrelerindeki kişileri, kendilerinden daha öne koyduğu ve haklarını çiğnemelerine izin verdiği için "hayır" demekte zorlanır. Bu ve benzer nedenlerle kendi istek ve duygularını ortaya koymak yerine çevresindekilerin istediği gibi davranır. "Hayır" dediği zaman; bir daha aranmamaktan, sevilmemekten, kabul edilmemekten korkar. Hayır demenin bencillik olduğunu, çevrenin isteklerini reddettiğinde kendisinin de onlardan bir şey isteme hakkının kalmayacağını düşünür (Davaslıgil ve diğerleri, 1998).

Problem Çözme: Heppner'e göre problem çözme, problemlerle başa çıkma kavramı ile eş anlamlıdır. Gerçek yaşamda kişisel problem çözme bu tanımda, iç ya da dış istekler ya da çağrılara uyum sağlamak amacı ile davranışsal tepkilerde bulunma gibi bilişsel ve duygusal işlemleri hedefe yöneltmek olarak ele alınmıştır (Heppner, 1987).

Problem çözme kavramı farklı alanlarda ve disiplinlerde farklı anlamlara sahiptir. Eğitimde ise problem çözme, bireylere gelecekte karşılaşabilecekleri problemlerin üstesinden gelebilecek becerileri kazandırma hedefi çerçevesinde ele alınmaktadır. Lester (1994), öğrencilere bu becerileri kazandırmanın ancak problem çözmenin eğitimin merkezinde olmasıyla mümkün olabileceğini dile getirmiştir (Akt: Karataş ve Güven, 2003).

\section{Yöntem}

Araştırma Modeli: Bu araştırma betimsel nitel bir araştırmadır. Araştırmada; Milli Eğitim Bakanlı̆̆ı'na bağlı Mihriban Suat Bedük İlköğretim Okulunda 8. sınıf öğrencileri ile yaşam becerileri eğitiminin drama yöntemi ile işlenmesinin iletişim, kendini tanıma, özgüven, "hayır” diyebilme, problem çözme gibi yaşam becerilerine ilişkin farkındalık düzeyine etkisi üzerinde durulmuştur.

Uygulama sürecinde, yaşam becerilerine ilişkin belirlenmiş olan konu başlıkları (iletişim, kendini tanıma, özgüven, "hayır" diyebilme, problem çözme) yaratıcı drama yöntemi kullanılarak işlenmiştir. Belirlenen konu başlıkları doğrultusunda toplam 10 oturum ve her oturum iki saatlik süreler halinde 
planlanmıştır. Uygulama toplam 20 saat sürmüştür. Oturumlar beş hafta süresince haftada iki oturum şeklinde uygulanmıştır.

Araştırmanın Örneklemi: Araştırmada çalışma kolaylığı açısından kısıtlı örnekleme yoluna gidilmiştir. Buna göre örneklem, araştırma İstanbul ili Üsküdar ilçesi Milli Eğitim Müdürlüğü’ne bağlı Mihriban Suat Bedük İlköğretim Okulu 8. sınıfinda okumakta olan daha önce yaratıcı drama yaşantısı olmayan, yaşları 13 ve 14 olan 8 kız, 7 erkek toplam 15 öğrenciden oluşmuştur. Öğrenciler 8/A ve 8/B şubelerinde okuyan istekliler öğrenciler arasından belirlenmiştir.

Araştırma Yöntemi: Bu araştırma, Milli Eğitim Bakanlığı'na bağlı Mihriban Suat Bedük İlköğretim Okulunda okuyan 8. sınıf öğrencileri ile yaşam becerileri eğitiminin drama yöntemi ile işlenmesinin yaşam becerilerine yönelik farkındalık düzeyine etkisini belirlemek amacıyla yapılmıştır. Araştırma sonucunda elde edilen veriler nitel araştırma yöntemi olan içerik analizi kullanılarak yapılmıştır.

Nitel araştırma; gözlem, görüşme ve doküman analizi gibi niteliksel veri toplama yöntemlerinin kullanıldığı, algıların ve bu olayların doğal ortamda gerçekçi ve bütüncül bir biçimde ortaya konmasına yönelik nitel bir sürecin izlendiği araştırma olarak tanımlamak mümkündür (Şimşek ve Yıldırım, 1999).

Nitel araştırmada en önemli amaçlardan biri araştırmaya dahil edilen bireylerin algılarının ve deneyimlerinin ortaya konmasıdır. Araştırmaya katılan bireylerden nicel araştırmalarda olduğu gibi bir teste yanıt vermeleri ya da daha önceden formüle edilen sınırlı sorulardan oluşan bir anketi doldurmaları beklenmez. Araştırmaya dahil edilen bireyler önemli veri kaynakları olarak kabul edilir ve onların vereceği yanıtları daha önceden oluşturulan sorularla sınırlandırmak mümkün değildir.

Algıların ortaya konmasında ve yorumlanmasında görüşmeler, araştırmacı için büyük önem taşır. Görüşmelerde elde edilen betimsel veriler daha sonra yapılacak analizlerin temelini oluşturur (Şimşek ve Y1ldirım, 1999).

Nitel araştırmada toplanan veriler nicel araştırmada olduğu gibi sayılara indirgenemez. Her ne kadar nitel yöntemlerle toplanan veriler üzerinde bazı sayısal analizler yapmak mümkün ise de, nitel araştırmada temel amaç sayılar yoluyla sonuçlara ulaşmak değildir. Asıl amaç, araştırılan konu ile ilgili okuyucuya betimsel ve gerçekçi bir resim sunmaktır. Bunun için de toplanan verilerin ayrıntılı ve derinlemesine olması ve araştırmaya konu olan bireylerin görüş ve deneyimlerinin mümkün olduğu ölçüde doğrudan sunulması önemlidir. Gerek görüşmeler gerekse gözlem ve dökümanları yoluyla elde edilen verilerin ayrıntılı ve derinlemesine olması, araştırma sonucunda ulaşılan sonuçların geçerlik ve güvenirliğine ilişkin önemli bir göstergedir (Şimşek ve Yıldırım, 1999).

Veri Toplama Aracı: Görüşme formunda, konu ile ilgili literatür tarandıktan sonra yaşam becerilerine ilişkin temel boyutlar oluşturulmuş ve her bir boyutu kapsayan sorular hazırlanmıştır. Hazırlanan sorulara uzman görüşleri doğrultusunda son şekli verilmiştir. Araştırmada veriler araştırmacı tarafindan hazırlanan yarı yapılandırılmış görüşme formu kullanılarak toplanmıştır. Görüşme formu toplam dokuz 
sorudan oluşmaktadır. Uzman kanısına dayalı geçerlik çalışması için ölçek, yaratıcı drama, iletişim ve ölçme değerlendirme alanlarında çalışmaları olan uzmanlar tarafından incelenmiştir.

Verilerin Analizi ve Görüşmelerin Yapılması: Bu araştırmada veriler İçerik Analizi tekniği ile çözümlenmiştir. Bunun için yazılı materyaller metodolojik olarak analiz edilmiştir. Bu çerçevede, mesajlar ve onların içindeki bilgiler sistematik olarak kodlanmıştır. Bunun için; temel olarak birbirine benzeyen veriler belirli kavramlar ve temalar çerçevesinde bir araya getirilmiş ve bunlar okuyucunun anlayabileceği bir biçimde organize edilerek yorumlanmıştır.

Görüşmeler yazılı olarak yapılmıştır. Ayrıntılar konusunda emin olabilmek için gereken yerlerde açıklamalar yapılmıştır. Görüşmeye katılan öğrencilerin kendilerini isim vererek tanıtma zorunda olmamalarının araştırmaya katılan görüşmecilerin yanlış cevap verme gerekçelerini önemli ölçüde ortadan kaldırdı̆̆ı düşünülmektedir.

\section{Bulgular ve Yorum}

Eğitim sonunda öğrencilere uygulanan görüşme formunda öğrencilerin verdikleri yanıtlar nitel araştırma yöntemlerinden içerik analizi tekniği ile çözümlenerek aşağıdaki sonuçlar elde edilmiştir.

Soru 1. Yaratıcı drama oturumlarında yaşam becerilerinden 5 tanesi üzerinde durduk. Yaptığımız etkinlikleri düşünerek bu yaşam becerilerinden hangilerini hatırlıyorsunuz?

Katılımcıların görüşleri aşağıdaki gibi sıralanmış, aynı görüşü belirten katılımcılar için, maddenin karşısına frekansı belirtilmiştir.

İletişim (15)

Kendini Tanıma (15)

Özgüven (15)

Hayır Diyebilme (15)

Problem Çözme (15)

Katılımııların tamamının işlenmiş olan yaşam becerilerinin beş tanesinin de adlarını hatırladıkları görülmektedir.

Soru 2. 5 yaşam becerisini drama etkinlikleriyle ele aldık. Yaşam becerilerinin bu yöntemle işlenmesi hakkında ne düşünüyorsunuz?

Katılımcıların görüşleri aşağıdaki gibi sıralanmış, aynı görüşü belirten katılımcılar için, maddenin karşısına frekansı belirtilmiştir.

a. Yaşamın içinden olan konuların yaşayarak işlenmesi öğrenmeyi kolaylaştırdı. (11)

b. Oyunların olması yöntemi zevkli ve eğlenceli hale getiriyor.(4)

Yaşam becerilerinin, yaşamın içindeki konular olması ve dramanın da yaşamdan yola çıkarak olayları ele almasının katılımcılar üzerinde olumlu etki yarattığ1 ve katılımcıların öğrenmeleri üzerinde olumlu etki yaptığı söylenebilir. Yaratıcı drama yönteminin içeriğinde bulunan oyunların öğrencilerin sıkılmalarını 
önlediği ve derslere daha fazla aktif katılım sağlayarak öğrenmelerini kolaylaştırdığı söylenebilir.

Soru 3. Yaratıcı drama oturumlarında edindiğiniz kazanımların günlük yaşamınız üzerinde olumlu etkisi olacağını düşünüyor musunuz? Nası1?

Katılımcıların görüşleri aşağıdaki gibi sıralanmış, aynı görüşü belirten katılımcılar için, maddenin karşısına frekansı belirtilmiştir.

a. Olumlu etkisi oldu. Özellikle kişisel gelişimime etkisi oldu.(15)

Katılımcıların yaratıcı drama etkinlikleri ile işlenen yaşam becerilerine ilişkin kazanımlardan özellikle iletişim ve kişisel özelliklerine yönelik farkındalıklarını artırdıkları ve özgüvenlerini geliştirdikleri görülmektedir. Oturumlarda edindikleri kazanımların katılımcıların günlük yaşantılarında kolaylıklar sağladı̆̆ı söylenebilir.

Soru 4. Yaşam becerilerinin yaratıcı drama yöntemiyle işlenmesinin bu yaşam becerilerini öğrenmenize olumlu katkısı olduğunu düşünüyor musunuz? Nası1?

Katılımcıların görüşleri aşağıdaki gibi sıralanmış, aynı görüşü belirten katılımcılar için, maddenin karşısına frekansı belirtilmiştir.

a. Olumlu katk1 sağladığını düşünüyorum. Eğlenerek öğrenmek güzeldi. Öğrendiklerimin daha kalıc1 olduğunu düşünüyorum.(15)

Yaşam becerilerinin, klasik yöntemler dışında, katılımcıların da içinde olduğu, oyunlarla desteklenen, canlandırmalar yapılan, grup bilincinin oluşmasına yardımcı olan, katılımcılara kendilerini rahat ifade etme olanağı tanıyan ve kendi yaşantılarından örneklerle destekleyen yaratıcı drama yöntemi ile işlenmesinin katılımcıların öğrenmeleri ile ilgili algıları üzerinde olumlu katkı sağladığı görülmektedir.

Soru 5. Yaratıcı drama etkinlikleri kendi yaşam becerilerinize ilişkin olarak duygu ve düşüncelerinizi fark etmenizde ne gibi katkılar sağladı?

Katılımcıların görüşleri aşağıdaki gibi sıralanmış, aynı görüşü belirten katılımcılar için, maddenin karşısına frekansı belirtilmiştir.

a. Kişisel özelliklerimin farkına vardım.(9)

b. İletişim becerilerim gelişti.(6)

Kendi yaşam becerilerine ilişkin olarak kendi kişisel özelliklerini daha çok tanımalarına olanak tanıdığg, bu özelliklerin farkına varmalarının kendi kişisel gelişimleri açısından önemli olduğu söylenebilir. Kalabalık bir grup içinde rahatlıkla hareket etmeleri ve kendilerini rahatlıkla ifade etmeleri kendilerine güven duymalarına ve kişilik özelliklerini daha iyi yansıtmalarına dolayısı ile iletişim becerilerinin olumlu yönde değişmesine olanak sağladığı görülmektedir.

Soru 6. Yaşam becerileri konusunun işlenişinde sevdiğiniz yönleri belirterek nedenini açıklar mısınız?

Katılımcıların görüşleri aşağıdaki gibi sıralanmış, aynı görüşü belirten katılımcılar için, maddenin karşısına frekansı belirtilmiştir. 
a. Çekinmeden rahat hareket edebilmek.(7)

b. Grup halinde çalışmak.(3)

c. Oyunlar oynamak ve doğaçlama yapmak.(5)

Katılımcıların yaratılan ortamın rahatlığından dolayı kendilerini rahat hissettikleri, kendilerini rahat hissettikleri için de kendilerini ifade ederken zorlanmadıkları ve çekinmedikleri, ortamda rahat hareket edebildikleri için de bu durumdan memnun kaldıkları söylenebilir.

Katılımcıların grup bilinci ile hareket etmekten, bir gruba ait olma duygusu yaşamaktan ve grupla oyunlar oynamaktan memnun oldukları söylenebilir.

Katılımcıların oyun oynamayı oldukça sevdikleri etkinliklerin oyunlarla desteklenmesinin katılımcıları memnun bıraktığı ve etkinlikler sonunda yapılan doğaçlamanın da katılımcıları memnun ettiği söylenebilir.

Soru 7. Yaşam becerileri konusunun işlenişinde sevmediğiniz yönleri belirterek nedenini açıklar mısınız?

Katılımcıların görüşleri aşağıdaki gibi sıralanmış, aynı görüşü belirten katılımcılar için, maddenin karşısına frekansı belirtilmiştir

a. Herhangi bir olumsuzluk yoktu. (14)

b. Bazı kişilerin tedirgin olması .(1)

Yaşam becerilerinin işlenişinden yana bir memnuniyetsizlik olmadığı bazı katılımcıların başlarda gösterdiği tedirginliğe yönelik bir memnuniyetsizlik olduğu söylenebilir.

Soru 8. Yaratıcı drama oturumlarında kendinizi yeterince ortaya koyduğunuzu, kendinizi olduğunuz gibi yansıttığınızı düşünüyor musunuz? Neden?

Katılımcıların görüşleri aşağıdaki gibi sıralanmış, aynı görüşü belirten katılımcılar için, maddenin karşısına frekansı belirtilmiştir.

a. Evet. Kendimi ortaya koydum.(10)

b. Zaman içerisinde dersler ilerledikçe kendimi ortaya koydum.(5)

Yaratıcı drama etkinlikleri ile yapılan derslerde katılımcıların kendilerini oldukça rahat hissettikleri ve konuları kendilerine yakın buldukları için kendilerini ifade ederken herhangi bir şekilde zorlanmadıkları; bunun için de kendilerini oldukça rahat bir şekilde ifade etmekten yana çekingenlik duymadıkları söylenebilir.

Yaratıcı drama etkinlikleri ile yapılan dersler de bazı katılımcıları utangaçlık, dalga geçilme gibi kişisel özelliklerinden dolayı kendilerini ilk oturumlarda yansıtmaktan ve katılım göstermekten çekindikleri fakat daha sonra ilerleyen oturumlarda arkadaşlarının ve öğretmenlerinin de desteği ile bu duygularının azaldığı ve kendilerine ait özellikleri yansıtmakta çekinmedikleri söylenebilir.

Soru 9. Genel olarak yaşam becerileri ile ilgili yaptığımız yaratıcı drama etkinlikleri hakkında ne düşünüyorsunuz? Açıklar mısınız?

Katılımcıların görüşleri aşağıdaki gibi sıralanmış, aynı görüşü belirten katılımcılar için, maddenin 
karşısına frekansı belirtilmiştir.

a. Derslerin eğlenceli, kendini ifade edebileceğin bir ortamda yaratıcı drama gibi yöntemle işlenmesi öğrenmeyi kolaylaştırır.(11)

b. Derslerin yaratıcı drama ile işlenmesi katılımcıları rahatlatır ve derslere daha fazla katılımda bulunmalarını sağlar.(4)

Yaratıcı drama etkinlikleri ile yapılan derslerde katılımcıların kendilerini rahat hissettikleri ve etkinlikleri eğlenceli buldukları için bu durumun öğrenmeleri üzerinde olumlu etkisi olduğu ve kalıcılığ pekiştirdiği söylenebilir.

Yaratıcı drama etkinlikleri ile yapılan çalışmaların katılımcıların rahatlamasına ve kendilerini güven verici bir ortamda olmalarına imkân sağladığı ve bu nedenle katılımcıların kendileri ifade ederken zorlanmadığı ve çekinmediğinden çalışmalara daha fazla katılım sağladığı söylenebilir.

\section{Sonuç ve Öneriler}

Katılımcıların yaşam becerilerine ilişkin olarak hazırlanan etkinliklerin yaratıcı drama yöntemi ile işlenmesinden memnun oldukları, yaratıcı dramanın yöntem olarak kullanılmasının öğrenmeleri üzerinde olumlu etki yaptığı ve etkinliklere aktif katılım sağlayıp fikirlerini rahatça ifade edebildikleri görülmektedir.

Yaşam becerilerinin geleneksel yöntemler dışında oyunlarla desteklenen, öğrencileri aktif kılan, canlandırmaların ve doğaçlamaların yer aldığı yaratıcı drama yöntemi ile işlenmesinin öğrencilerin kendilerini rahat ifade etmesini sağladığı söylenebilir. Ayrıca yaratıcı drama etkinliklerinde kendi yaşantılarından yola çıkılmasının da öğrencilerin öğrenmelerini kolaylaştırdığı ve kalıcılığı $\operatorname{artırdığ~}$ söylenebilir.

Öğretmenlere yaratıcı drama yönteminin tanıtılması ve bu yönde M.E.B ile işbirliğine gidilerek öğretmenlere yönelik eğitimlerin düzenlenmesi yararlı olabilir

Öğrencilere yönelik olarak yapılan ve farkındalık kazandırmaya yönelik olan derslerin yaratıcı darama yöntemi ile yapılması yararlı olabilir ve öğrencilerin daha fazla katılım sağlaması yönünde etkili

olabilir. Öğrencilerin olumlu davranış geliştirme, tüm dersler için duyuşsal boyuta yönelik kazanımların geliştirmesinde yöntem olarak yaratıcı drama kullanılabilir.

Yaşam becerileri alanında çalışma yapmak isteyenler; diğer yaşam becerilerine ilişkin etkinlikleri drama yöntemini kullanacak şekilde düzenleyerek bu yöntemin yaşam becerilerinin farkındalık düzeyine etkisi üzerine araştırma yapabilirler.

Ayrıca, yaşam becerilerine ilişkin farkındalık kazandırmada yöntemlerin etkisi arasında anlamlı fark olup olmadığını ön test son test yöntemi ile test edebilirler.

Ayrıca, deney ve kontrol gruplu çalışmalar yapılarak ve iki gruba da öntest ve sontest uygulanarak farkındalıkları, öğrenme düzeyleri ve öğrenmelerin kalıcılığı üzerinde fark olup olmadığına yönelik bir çalışma yapılabilir. 


\section{Kaynaklar}

Adıgüzel, Ö. (1993). “Oyun ve yaratıcı drama ilişkisi.” Yayımlanmamış Yüksek Lisans Tezi, Ankara Üniversitesi, Ankara

Cüceloğlu, D. (1991). Yeniden insan insana. İstanbul: Remzi Kitabevi.

Davaslıgil, Ü., Çakıcı, M., Ögel, K. (1998). "Yaşam becerilerini geliştirme kılavuzu.” Bağımlılık ve Gençlik Komisyonu Eğitici Kılavuzu.

Erbil, O.., Demirezen S., Erdoğan A., Terzi Ü., Eroğlu H., ve Ergin, A. B. (2000). Eğitimde iletişim. Ankara: Anı Yayınc1lı.

Hawkins, E. H.; Cummins, L. H.; Marlatt, G. A. (2004). Preventing substance abuse in

American indian and alaska native youth: promising strategies for healthier communities.

Psychological Bulletin. Vol. 130, No. 2. 304-323

Heppner, P. Krauskopf, K. (1987). An infromation processing apporach to personal problem solving.

The Counseling Psychologist. Vol:15, s- 34-37

Karataş, İ ve B. Güven (2003). 8. Sınıf öğrencilerinin problem çözme becerilerinin belirlenmesi: Bir özel durum çalışması. Milli Ĕgitim Dergisi, Sayı:163

Kendini Tanıma. (t.y.). Erişim: 8 Şubat 2009, http://www.psikiyatrihemsireligi.com

Kendini Tanıtma. (t.y.). Erişim: 6 Şubat 2009, http://www.tathli.com/kendini-tanima-kendini-tanitma t29366/index.html?s=6946e3c3543c448062a25d24904d1e85\&amp;

Life Skills. (t.y.).Erişim: 23 Ocak 2009, www.extension.iastate.edu/4H/lifeskills/homepage.html

Masalcı, A. D. (2001). Aile içi etkileşimlerle çocuğun saldırganlık düzeyi ve uygun davranışlarının karşılaştırılması. Yayınlanmamış Yüksek Lisans Tezi. Dokuz Eylül Üniversitesi Eğitim Bilimleri Enstitüsü, İzmir

Mckay M. ve Fanning P. (1998). Özgüven Yaratılması ve Korunması. Çeviren: Anita Tatlıer, İstanbul: Epsilon Yayınevi.

Oskay, Ü. (2001). Illetişimin ABC'si. İstanbul: Der Yayınları.

Özer, A. (2001). İletişimsizlik Becerisi. İstanbul: Sistem Yayıncılık.

Özbey, Ç. (2004). Çocuk sorunlarına yapıcı çözümler. İstanbul: İnkılâp Kitabevi.

Picklesimer, B.K. \& Miller, T.K. (1998). Life-skills development inventory-college form: An assessment measure. Journal of College Student Development, 39(1), 100-110.

Şimşek, A. ve H. Yıldırım (1999). Sosyal Bilimlerde Nitel Araştırma Yöntemleri, Ankara: Seçkin Yayınevi

Yaşam Becerileri. (t.y.). Erişim: 23 Ocak 2009, www.15.hrdc.drhc.gc.ca/English/general/intro.asp 


\section{EK-1}

\section{OTURUM}

Tarih: 30.04.2009

Mekân: Mihriban Suat Bedük İlköğretim Okulu Çok Amaçlı Salonu

Konu: İletişim

Süre: $40+40+40 \mathrm{Dk}$.

Yöntem: Yaratıcı Drama

Teknik: Rol Oynama, doğaçlama

Araç Gereçler: CD çalar, Müzik CD'si, kalem, kâğıt, hayat kutusu formu, 4 farklı renkte A4 kağıdı.

Isinma

Etkinlik 1: Katılımcılardan verilen yönerge doğrultusunda hareket etmelerini istenir. Katılımcılardan salonda göz teması kurarak yürümeleri ve sırayla verilen duruma uygun davranmaları istenir.

o Karşıdan sevmedikleri bir kişi geliyor ve selam veriyorlar.

o $\quad$ Çok sevdikleri bir kişiyi görüyorlar ve selam veriyorlar.

o Patronlarını görüyorlar ve selam veriyorlar.

o $\quad$ Öğretmenlerini görüyorlar ve selam veriyorlar.

Etkinlik 2: Tilki ile Tavşan: Katılımcılardan ikili olarak birbirlerinin kollarına girmeleri istenir. Boşta kalan taraftaki kollarının bellerine konulması istenir ve bunun yuvayı oluşturacağı açıklanır. Bu şekilde oluşan yuvalar mekân içinde dağınık bir düzende yerleştirilir. Belirlenen iki kişiden biri tilki diğeri tavşan rollerini alır. Tilkinin tavşanı kovalaması ile oyun başlar. Oyun sırasında tavşan kaçması ve saklanması için eşlerin boşta kalan kolları ile oluşturdukları yuvalara girmesi gerekmektedir. Ancak bu durumda tavşanın girdiği yuvanın eşi tavşan rolünü alır ve tilkiden kaçmaya devam eder. Tilki kaçan tavşanlardan birini yakaladığında kurtulur ve yakalanan kişi tilki olur.

Etkinlik 3: Lider katılımcılardan en yakınlarındaki kişi ile ikili olmalarını ve kendi aralarında A ve B olmak üzere ikiye ayrılmalarını ister. Salonda bir yerde oturarak ya da ayakta önce A'nın kendini tanıtmasını daha sonra aynı şekilde B'nin kendini tanıtmasını ister. Bunun için katılımcılara belli bir süre verilir. Tanışma tamamlandıktan sonra ikili grupların çember oluşturacak şekilde oturmaları istenir. Sonra her gruptan sırayla tüm gruba arkadaşlarını tanıtmaları istenir.

Etkinlik 4: Katılımcılardan kendilerine daha önceden tanımadıkları bir eş bularak ikili gruplar oluşturmaları istenir. Daha sonra "Hayat Kutusu formu" dağıtılarak eşlerine sormadan, sorulan soruları tahmin ederek cevaplamaları istenir. Daha sonra formları birbirine vererek herkesin kendisi ile ilgili cevaplarını da yazmaları istenir. Ardından sorulara verilen cevaplar karşılaştırılır.

\section{Canlandirma}

Etkinlik 5: Katılımcılar 4 gruba ayrılır. Katılımcılara tanışmayı çok istedikleri bir kişi ile röportaj yapacakları söylenir. Bunun için o kişiye sorulmak üzere çok özel olmayan genel olarak hazırlanmış en az 5 tane soru hazırlamaları ve soruları lidere vermeleri gerektiği belirtilir. Soruları hazırlamaları 
için katılımcılara süre verilir. Daha sora hazırlanan sorular katılımcılar tarafından lidere verilir. Her gruba kendi içlerinden bir kişi seçmeleri söylenir. Lider kâğıtları gruplara kendi hazırladıkları sorular gelmeyecek şekilde dağıtır ve bu soruları kendi içlerinden seçtikleri kişilere göstermemeleri söylenir. Röportaj yapacakları kişinin kısa bir süre önce geçirdiği bir kaza yüzünden geçici bir süre duyamadığ ve konuşmasının da kesinlikle yasak olduğu belirtilir. Soruları ancak bu şekilde sorabilecekleri ve zamanlarının kısıtlı olduğu belirtilir. Hazırlanmaları için katılımcılara süre verilir. Gruplar canlandırmalarını sunarlar.

\section{Değerlendirme}

Etkinlik 6: Katılımcılara aşağıdaki sorular yöneltilir.

1.İletişim kurarken nelere dikkat ettiniz?

2. Grup içinde hangi arkadaşınızı daha fazla tanıdınız? Neden?

3.Hangi arkadaşınızı daha az tanıdınız? Neden?

\section{EK-2}

\section{GÖRÜŞME SORULARI}

1. Yaratıcı drama oturumlarında yaşam becerilerinden 5 tanesi üzerinde durduk. Yaptığımız etkinlikleri düşündüğünüzde bu yaşam becerilerinden hangilerini hatırlıyorsunuz?

2. 5 yaşam becerisini drama etkinlikleriyle ele aldık. Yaşam becerilerinin bu yöntemle işlenmesi hakkında ne düşünüyorsunuz?

3. Yaratıcı drama oturumlarında yaşam becerileri konusunda neler kazandığınızı düşünüyorsunuz? Edindiğiniz kazanımların günlük yaşamınız üzerinde olumlu etkisi olacağını düşünüyor musunuz? Nasil?

4. Yaşam becerilerinin yaratıcı drama yöntemiyle işlenmesinin bu yaşam becerilerini öğrenmenize olumlu katkısı olduğunu düşünüyor musunuz? Nasıl?

5. Yaratıcı drama etkinlikleri kendi yaşam becerilerinize ilişkin olarak duygu ve düşüncelerinizi fark etmenizde ne gibi katkılar sağladı?

6. Yaşam becerileri konusunun işlenişinde hoşlandığınız yönleri belirterek nedenini açıklar misiniz?

7. Yaşam becerileri konusunun işlenişinde hoşlanmadığınız yönleri belirterek nedenini açıklar misiniz?

8. Yaratıcı drama oturumlarında kendinizi yeterince ortaya koyduğunuzu, kendinizi olduğunuz gibi yansıttığınızı düşünüyor musunuz? Neden?

9. Genel olarak yaşam becerileri ile ilgili yaptığımız yaratıcı drama etkinlikleri hakkında ne düşünüyorsunuz? Açıklar mısınız? 


\title{
Summary \\ Using Of Creative Drama Methods In Gaining Living Skills*
}

\author{
Selçuk Rafet SEFER ${ }^{1} \quad$ O. Nejat AKFIRAT ${ }^{2}$ \\ Ministry of National Education
}

Competencies of life, is the satisfactoriness one requires to continue its existence in an efficient way (Erbil et. al., 2000).

The competencies of life have been determined to be the ones one requires to fulfill the necessities of daily routines and responsibilities. These competencies are more likely concerned with professional life. According to the description, the competencies of life comprises of the activities one has to fulfill in his/her professional life and daily routines, the requirements to acquire to new things, adapt itself to the changes experienced and help them develop their qualifications in their fields.

The competencies of life are different from those that are essential in academic fields. Competencies of life decrease the state of being identified and labeled with misbehavior. The students will be more likely to be interested in facility and experiences that would help them struggle with life itself.

The competencies of life, which is aimed to be gained by students are the competencies that all individuals are expected to possess, is believed to be more effective when provided with a creative drama method applied.

It is well known that the methods, techniques and strategies applied in education are effective aspects in one to acquire and gain any new knowledge and experience. Therefore, it is very important to choose the most suitable method, technique and strategy to keep students alive and aware of the topic while providing education together in a motivated mood.

The easiest easy to keep students active and motivated is to activate them during education and benefit from their past experiences. Creative drama, thus, is one of the methods that serve such aim in education (Adigüzel, 1993).

It is assumed that passing from one stage to another stage in creative drama, the activities and experiences increase the awareness of students whilst decreasing the duration of providing their compatibilities to the new topic.

This study focuses on five main competencies which are as: Communication, Recognition of Oneself, Self Confidence, Ability to say 'No', and Solving Problems.

\footnotetext{
* This article was written from MEB Dogac Creative Drama Leadership's/Educator's Course Final Project.

1 Ms. Ministry of Education, E-posta: srsefer@gmail.com

2 Dr. Ministry of Education, E-posta: nejatakfirat@gmail.com
} 
This study, which was prepared aiming to increase the awareness of competencies of life, has been realized with the part icipation of 15 students, who has no previous experience in creative drama, studying in the eighth grade at Mihriban Suat Bedük Primary School at Üsküdar, Istanbul in connection with the Directorate of Education.

The research data has been collected via the intercourse forms applied which were prepared by experts. The data has been assessed by context analysis.

In the research; it has been focused on the level of awareness and affects over the students, who are occupied as pupils at Mihriban Suat Bedük Primary School, eighth graders, on creative drama concerning life competencies.

In the conclusion of the research it was detected that the creative drama method applied had positive impacts on their learning and that the participants were satisfied with the application.

It is detected that creative drama, especially when compared with classical methods, provided participants and students to take place more actively, demonstrate the activities in a more comfortable way where they can express themselves effectively and increase their motivation, thus, ease their learning as well.

It was detected that the participants felt comfortable in expressing themselves as the environment the drama was realized in was comfortable and supportive. Therefore, such an ambience led students to express themselves and eventually participate more actively.

When all these facts are considered, it is thought that all lessons that aim to provide and increase awareness could be realized with the creative drama method. The lessons which are realized with the creative drama method will also provide students to take part more actively and eventually remain with better experience in learning. Considering all these positive impacts, it is believed that creative drama could be applied in all fields and lessons that aim to develop and increase students gain a dimension of affective education. 